\title{
The role of molecular markers and marker assisted selection in breeding for organic agriculture
}

\author{
E. T. Lammerts van Bueren - G. Backes • \\ H. de Vriend $\cdot$ H. Østergård
}

Received: 16 October 2009/Accepted: 12 April 2010/Published online: 24 April 2010

(C) The Author(s) 2010. This article is published with open access at Springerlink.com

\begin{abstract}
Plant geneticists consider molecular marker assisted selection a useful additional tool in plant breeding programs to make selection more efficient. Standards for organic agriculture do not exclude the use of molecular markers as such, however for the organic sector the appropriateness of molecular markers is not self-evident and is often debated. Organic and low-input farming conditions require breeding for robust and flexible varieties, which may be hampered by too much focus on the molecular level. Pros and contras for application of molecular markers in breeding for organic agriculture was the
\end{abstract}

E. T. Lammerts van Bueren ( $\square)$

Wageningen UR Plantbreeding, Wageningen University, P.O. Box 386, 6700 AJ Wageningen, The Netherlands

e-mail: edith.lammertsvanbueren@wur.nl

\section{G. Backes}

Faculty of Life Sciences, Department of Agriculture and Ecology, University of Copenhagen, Thorvaldsensvej 40, 1871 Frederiksberg C, Denmark

e-mail: guba@life.ku.dk

H. de Vriend

LIS Consult, Diederichslaan 25, 3971 PA Driebergen,

The Netherlands

e-mail: lisconsu@xs4all.nl

H. Østergård

Risø National Laboratory For Sustainable Energy,

Biosystem Division, Technical University of Denmark

DTU, P.O. Box 49, 4000 Roskilde, Denmark

e-mail: haqs@risoe.dtu.dk topic of a recent European plant breeding workshop. The participants evaluated strengths, weaknesses, opportunities, and threats of the use of molecular markers and we formalized their inputs into breeder's perspectives and perspectives seen from the organic sector's standpoint. Clear strengths were identified, e.g. better knowledge about gene pool of breeding material, more efficient introgression of new resistance genes from wild relatives and testing pyramided genes. There were also common concerns among breeders aiming at breeding for organic and/ or conventional agriculture, such as the increasing competition and cost investments to get access to marker technology, and the need for bridging the gap between phenotyping and genotyping especially with complex and quantitative inherited traits such as nutrient-efficiency. A major conclusion of the authors is that more interaction and mutual understanding between organic and molecular oriented breeders is necessary and can benefit both research communities.

Keywords Organic agriculture - Organic plant breeding - Evaluation of molecular markers . Marker assisted selection - SWOT analysis . Low-input agriculture

\section{Introduction}

Lately, the amount of molecular genetic markers for plant breeding relevant traits has increased. Plant 
geneticists and a growing number of plant breeders consider molecular marker assisted selection (MAS) a useful additional tool in plant breeding programmes to optimize selection efficiency (Dwivedi et al. 2007; Xu and Crouch 2008). However, although organic standards do not exclude the use of molecular markers as such, for the organic sector the appropriateness of molecular markers is not self-evident and is often debated (e.g. Lammerts van Bueren et al. 2005). This discussion is related to the fact that organic agriculture (OA) not only refrains from the use of chemical herbicides and pesticides and of mineral fertilisers, but also of genetically modified organisms (GMOs). These rejections are based on the basic values of organic agriculture, formulated as four principles of health, ecology, care and fairness (IFOAM 2005). These principles are also related to the field of plant breeding and provide guidelines for future development (Lammerts van Bueren et al. 2007; Wolfe et al. 2008; Dawson and Goldringer 2009; Grausgruber 2009; Luttikholt 2009). As a result, three types of questions are often raised in debates to argue why GMOs are not compatible with organic agriculture: (a) the supposed health and environmental risks, (b) the socio-economic threats of the dominance of multinationals controlling the agro-food industry and (c) the fact that GMOs are considered to be a product from a reductionist approach of life (Verhoog 2007). Although molecular markers are a diagnostic tool for selection and therefore not directly interfering or altering the genome at DNA level, still aspects related to the above mentioned aspects (b) and (c) play a role in the question whether molecular markers are an appropriate tool in breeding programme for organic agriculture (Lammerts van Bueren et al. 2005). The conclusion of a European plant breeding workshop on use of molecular markers organized in 2005 was that MAS as a diagnostic tool can be useful for breeding research, especially when monogenic traits are involved (Lammerts van Bueren et al. 2005). Nevertheless, most of the participants agreed that, on the short term, molecular markers would not be available for the more complex traits that are of specific interest for the practical breeding programmes for varieties for organic agriculture, such as nutrient-efficiency and weed suppressiveness. Therefore, phenotypic selection in the field was considered still to be the best way to select for organic agriculture. Another aspect of concern are the protocols during the development and application of molecular markers including chemical substances and enzymes produced with GMOs. Such chemicals and genetically modified enzymes are not permitted according to the US and EU regulations for organic agriculture including a limited list of permitted substances that can be applied (USDA 2002; Council of the European Union 2007).

In the past few years, with the introduction of new techniques for DNA extraction and high-throughput equipment, the molecular marker technology has evolved rapidly and practical breeders are gaining experience in the application of molecular markers in their breeding programmes. Furthermore, several conventional breeders are getting interested in breeding for the organic sector and, therefore, want to know to which extent molecular marker technology is accepted in breeding for OA. Both aspects provided sufficient reason to reconsider the potential role of molecular markers in plant breeding for OA and lead anew to the organization of a European workshop on this topic (Østergård et al. 2009a).

This paper will discuss the role of molecular markers and marker assisted selection in breeding varieties for OA, based on the authors' interpretation of the results of that recent workshop. We will first discuss what markers in general have to offer and afterwards we will discuss statements from the workshop grouped as strengths, weaknesses, opportunities and threats. The authors wish that this paper will contribute to further discussion among breeders aiming at breeding for organic and/or conventional agriculture and (research) policy makers on the potential role of molecular markers in crop improvement for organic, low-input agriculture.

\section{What have markers to offer?}

Since plant breeding by crosses and selection started in the beginning of the 20th century, experienced breeders know that certain phenotypically recognizable apparently neutral characteristics of a crop plant with large probability coincide with specific expressions of traits of importance for the breeder. Thereby, those characteristics 'mark' the desired or undesired individuals and are called 'phenotypic markers'. Their function is based on genetic linkage between the genes for the characteristics and the important traits. As phenotypic markers are rather rare and not 
available in every segregating population, their scale of application is limited. Therefore, the introduction of protein-based markers (isozymes) was a considerable improvement as about 26 widely used detection systems with up to ten loci per system became available (Kephart 1990). First the discovery of DNA markers, directly showing even unexpressed DNA sequence differences at or nearby loci for genes of interest, resulted in a (theoretically) unlimited number of potential markers (Lodish et al. 2004). Without the knowledge of linkage to genes for specific traits of interest (for the breeder) molecular markers can still be used to determine the genetic relatedness between two different individual plants or the genetic diversity within a gene pool. Linkage analysis based on the frequency of crossing-over events in segregating populations calculates the genetic distance between markers relative to each other and between markers and genes responsible for qualitatively inherited traits. Thereby, extensive linkage maps have become available for all major crops (Collard et al. 2005). QTL analysis tests for trait differences of individuals carrying different patterns of the same marker in order to place gene loci for quantitatively inherited traits on those maps. Thus, markers for quantitative traits can be identified (Yin et al. 2003). Even though increasing, the use of molecular markers is still modest in plant breeding at present. One major reason for this fact is the lack of appropriate markers with high selective value for many of the traits of interest for breeders (Tuvesson et al. 2009).

Four different developments have the potential to further promote the use of molecular markers. They are based on the increasing amount of sequence information and marker density in the genomes of important crop species, as well as progress in knowledge of the physiological background of the interaction of the plant with the environment: (a) Instead of linked markers, functional markers move into the focus of interest. Here, the difference in the sequence is not only linked to the marker with the specific trait expression, but directly responsible for the change in trait (Andersen and Lübberstedt 2003). Thus, linkage between marker and trait cannot be lost and the marker is fairly independent from the genetic background. (b) Associations between markers and traits are calculated based on crossing-overs that happened during the history of a certain gene pool. They manifest themselves as linkage disequilibrium
(LD) between the alleles of pairs of marker/gene loci. Typically, so-called LD- or association-mapping is used to identify QTLs. As many crossing-overs can have happened during time, they have, on the one hand, a higher resolution than QTL-mappings based on segregating populations, but on the other hand, linkage is only detectable through relatively short parts of the chromosome. Consequently, a high marker-density is necessary in these association studies, but on the other hand the so detected markers are valuable in a larger genetic background and there is no need for crossing in order to produce segregating populations (Gupta et al. 2005). (c) Prediction of the performance of a specific plant is based on the pattern of all markers in that plant instead of on single marker genes (Whole Genome Profiling) (Keygene 2009). This technique circumvents the need of first defining QTLs before using markers in order to select for complex traits. (d) For the case of quantitative traits largely depending on environmental factors, genotype $\times$ environment interactions are integrated in the QTL analysis resulting in markers reflecting the amount and direction of reaction of the plant to an environmental input. Those markers are valuable over a larger range of environments (Backes and Østergard 2008).

Plant breeders use molecular markers for different purposes. One application which is possible even without the genetic mapping of markers, is the control of genetic diversity within the pool of potential crossing parents in order to assure highest possible diversity within a cross, if several options are available (Tuvesson et al. 2007). If the mapping position of the marker is known and many parents and their progenies are tested with markers, it is possible to follow chromosome fragments in the pedigrees, thereby identifying fragments conferring 'positive' or 'negative' characteristics (Tuvesson et al. 2007). In MAS, the most straightforward application is to select for an allele of a linked marker in order to select for an allele of the linked gene (Collard et al. 2005). Several genes contributing to one trait, e.g. resistance, can be pyramided in one genotype by the use of linked markers. In backcross-designs, a further application is to speed up the process by selecting only individuals with the highest amount of the recurrent parent. Especially, with recessively inherited traits, slow and complex procedures using a progeny test (selfing after each backcross and 
identification of homozygous recessive plants) were required to track the target trait in each generation. Using molecular markers also heterozygous plants can be used for backcrossing until final selfing. Moreover, MAS is especially valuable for traits that are difficult or impossible to select e.g. in resistance breeding programmes when natural infestation by the pathogen is not available and/or artificial infestation is prohibited, e.g. quarantine pathogens. Although the above mentioned Whole Genome Profiling is to date primarily applied in domestic animals, it can be expected that also plant breeders will adapt that tool. Keygene recently started to screen about 7,000 tomato landrace varieties for 20 different markers (Keygene 2009). Further, it is possible to follow, by genotype-specific markers, the development of evolving population such as composite-cross populations in different environments (Lançon et al. 2008, Enjalbert et al. 1999, Wolfe 2009).

\section{SWOT analyses}

Pros and contras for use of molecular markers in breeding for OA were the topic of a recent European plant breeding workshop (Østergård et al. 2009a). The participants included scientists in the field of OA and conventional agriculture, and practical breeders involved in breeding for conventional and/or organic agriculture. The number of participants (46) were fairly equally divided over the different groups, and included also a few policymakers from the agricultural sector. The authors of this paper were amongst the participants.

At first, examples of MAS for wheat, potato and tomato disease resistance as well as baking quality of wheat were presented as well as the corresponding organic breeding programmes. Then the participants in mixed groups evaluated internal strengths (S) and weaknesses (W), and external opportunities (O) and threats (T) of the use of molecular markers using a SWOT instrument (see e.g. Mollenhorst and de Boer 2004). In this way, people with different opinions on the subject under study (use of molecular marker technology in OA agriculture) could express their opinion on helpful and harmful impacts on the objective (more and better varieties for organic agriculture) and ascribe them to internal or external conditions.
After the workshop, the authors divided the specific statements from the group SWOT evaluations into those related to the perspective of a breeder and those related to that of the organic sector (Tables 1 and 2, respectively); this grouping was done to clarify where issues and views overlapped and where they differed.

In general, there was reasonable consensus among the participants in identifying the different aspects of strengths and weaknesses, opportunities and threats. However, the weighting of the factors could differ very much. For some of the participants the threats were more of a concern and could be a reason for not appreciating the opportunities, whereas others were very positive about the strengths and seemed prepared to find ways to cope with the weaknesses or threats.

In the following, we will further analyse and discuss the main content of the tables. We have organized this part as well as the SWOT tables according to the main issues identified: breeding goals, selection method, selection potential, technology potential, consequences for breeders' and farmers' economy and societal consequences, respectively.

Meeting the needs of organic agriculture

Breeders stressed advantages of the use of molecular markers to improve varieties for the organic sector (Table 1, Strengths). Allowing the application of molecular markers in breeding programmes to improve varieties for $\mathrm{OA}$, would allow a breeder to combine breeding for OA with conventional breeding programmes for low-input agriculture.

The participants from the OA could also see some advantages of MAS as a non-GMO strategy to improve the efficiency of breeding programmes for urgently needed, better adapted varieties (Table 2, Strengths). MAS may help to overcome some hurdles, such as selection with pyramiding of (monogenic) resistance sources for potato late blight which is very difficult to achieve without molecular markers (Tan 2008). Phytophthora infestans is a real threat for OA and resistant varieties would improve the position of potatoes in organic farming (Lammerts van Bueren et al. 2008; Vos 2009). Although horizontal resistance with a polygenetic base is seen as more advantageous in OA, it is also recognized that such is not in all cases available or optimal (Finckh 2009). However, this strategy of stacking genes has to prove itself as a 


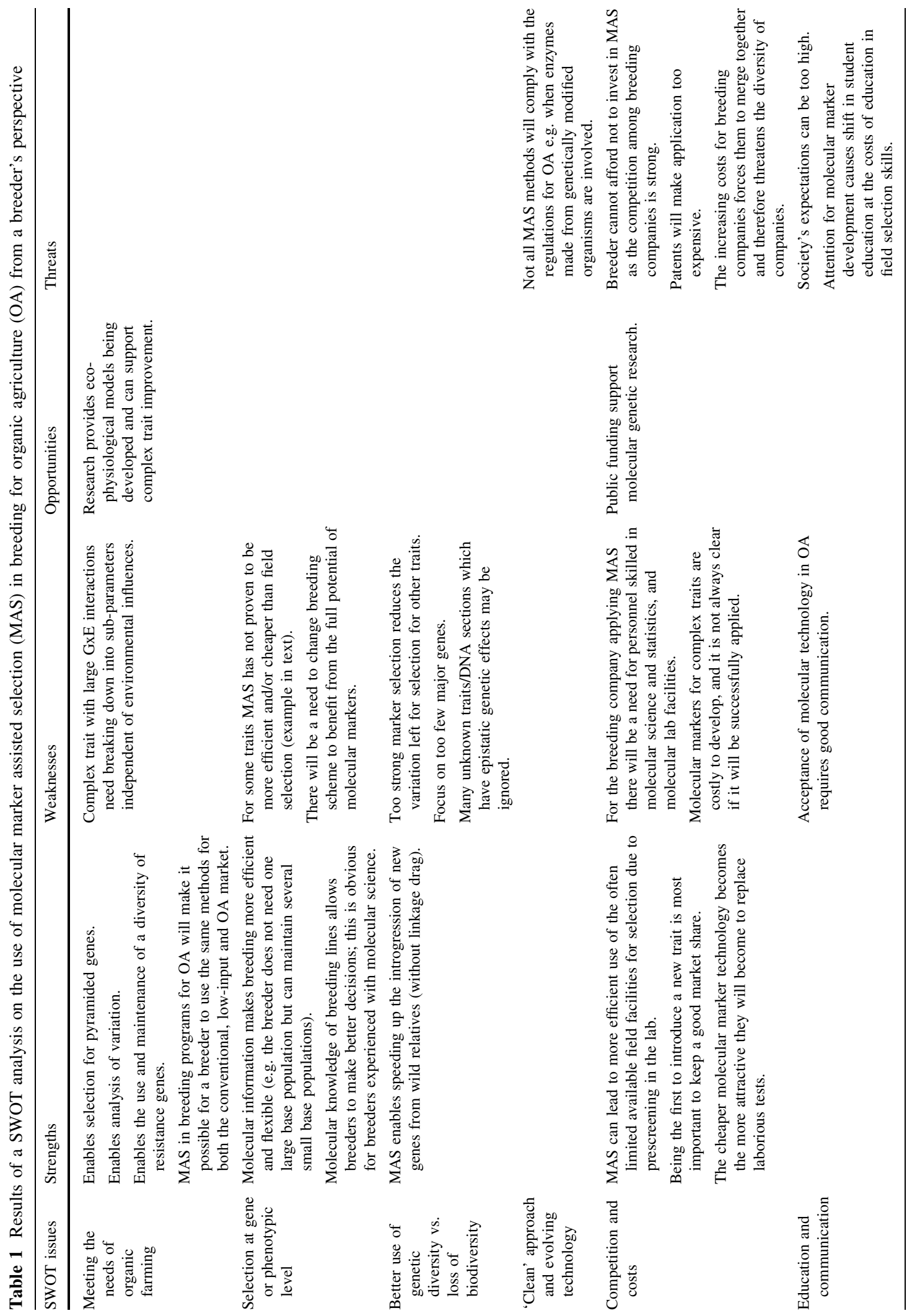



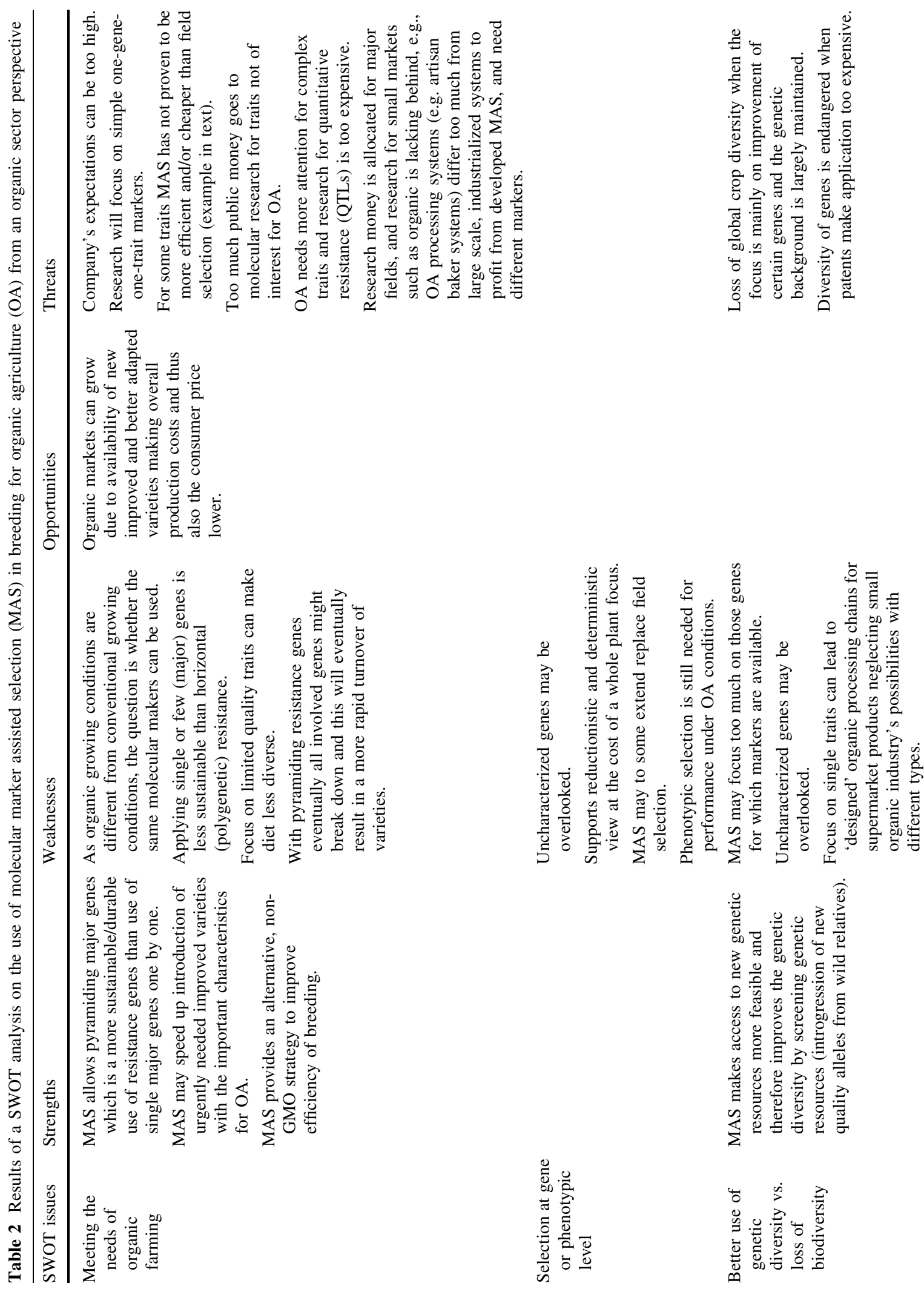


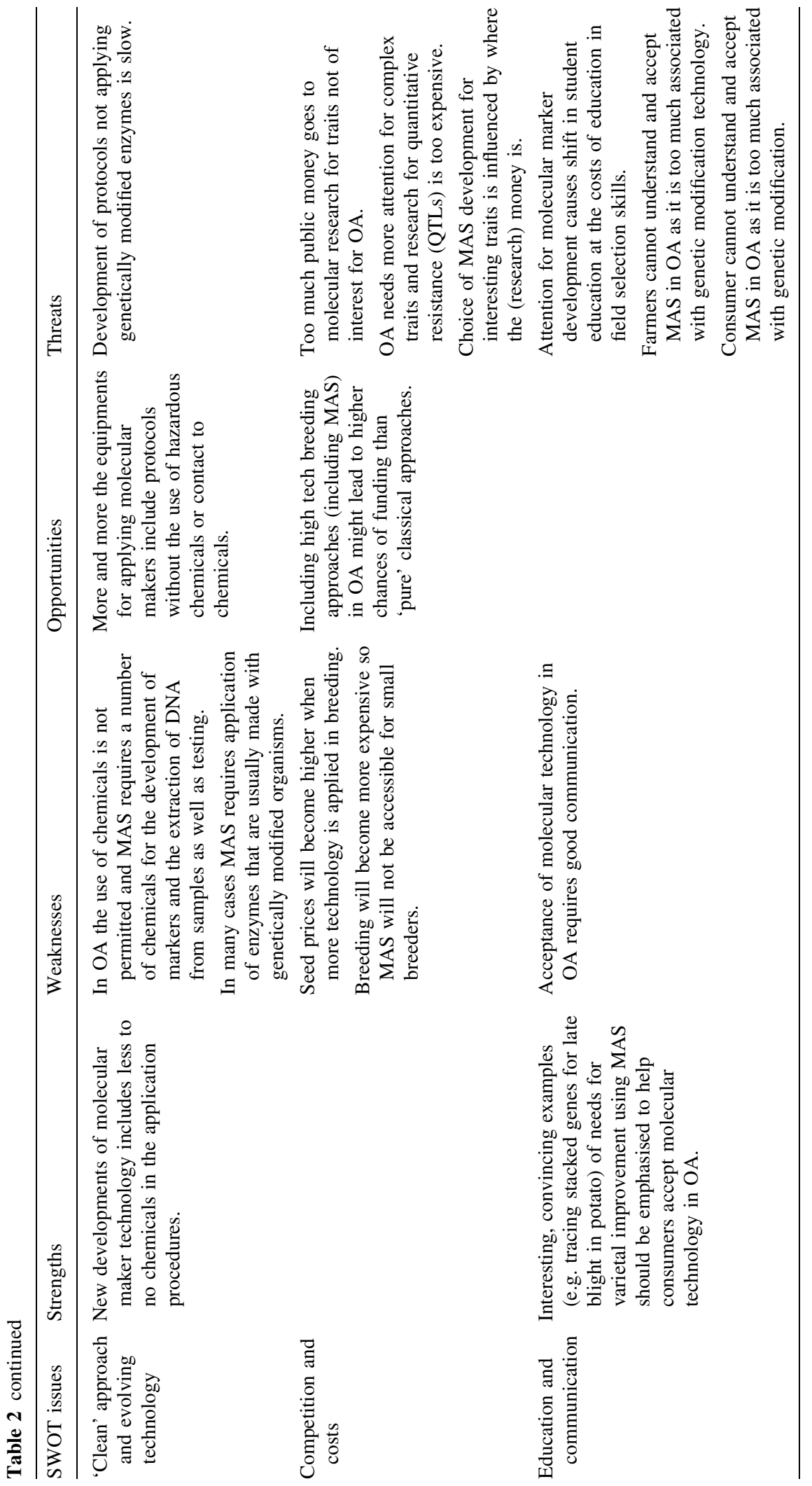


durable resistance strategy and apprehensions were expressed that a fail of this strategy would result in a loss of several resistance genes at a time and an even more rapid turn-over of varieties (Table 2, weakness). Whether this strategy will be applicable in the late blight case is still under discussion as the effectiveness of gene stacking for blight resistance in potato remains uncertain due to the evolutionary potential for rapid adaptability of $P$. infestans to host plants (Haas et al. 2009).

There was not much discussion about the use of molecular markers for specific monogenetic traits. However, there was more concern about the efficacy of molecular markers for quantitative traits. To create conditions to optimise yield stability and good quality, $\mathrm{OA}$ is stressing more emphasis on achieving varieties adapted to low-input growing conditions. The low-input management of OA results in a larger influence of varying environmental conditions (in time and geographically) on crop performance. To cope with varying environmental conditions, adaptive and robust varieties are required (Lammerts van Bueren et al. 2002, Wolfe et al. 2008). Specific for organic, low-input farming methods is the need for an adapted plant architecture above and below ground resulting in e.g. improved weed competitiveness and nutrient efficiency (e.g. Mason and Spaner 2006; Østergård et al. 2007). Traits such as nutrient efficiency are quantitative traits largely influenced by environment and management. Especially for such complex traits, the representatives of OA feared that marker research is too complicated and expensive (Table 2, Weaknesses). Further, there was the concern that markers developed under and for conventional conditions might not be effective, when applied in an organic context (Table 2, Weaknesses), e.g. with respect to markers for baking quality. First of all the baking procedures in the organic sector differ to a large extent from conventional baking that relies mainly on industrial baking procedures. Many organic bakeries do not work with frozen dough as the industrialized bakers do, so organic baking procedures require dough with less strong glutenin types. Thus the required phenotype in organic bread wheat production is different from conventional wheat production and therefore markers for conventional conditions may not always be relevant for organic conditions. Secondly, QTL may interact with environmental conditions. For instance, not only the protein level but also the protein composition can change under low-input growing conditions compared to high-input conditions (Wieser and Seilmeie 1998; Triboï et al. 2003; Tuvesson et al. 2009). In that case the same QTLs and/or the same power of the QTLs can not be automatically applied. Nevertheless, the organic sector would be interested in markers for baking quality under low-input growing conditions of wheat to replace the laborious and costly baking tests during the breeding process.

\section{Selection at gene or phenotypic level}

As selection is a key tool in breeding, this topic was dealt with from both the breeders and organic sector's perspective and was controversially discussed. As organic farmers have to rely on a diversity of measures that support and complement each other under varying conditions and as they have less means to promptly interfere and compensate during crop growth, there is more need for overall improved performance of a variety combining many desired characteristics to support yield stability. This requires a more holistic, integrated systems approach in designing the most appropriate set of measures, including crop improvement. In the OA sector, a primary reaction is often to consider genomics as a result of reductionist science and therefore not much of value for organic agriculture (Table 2, Weaknesses). Accordingly, the organic sector tends to put more emphasis on the weaknesses and threats (loss of diversity, high costs, narrow focus etc.) and is less inclined to appreciate the potential strengths and opportunities of molecular markers. Lack of knowledge of marker assisted selection procedures leads to fear that crops will be selected in the lab and no longer evaluated in the field.

Also breeders recognize the 'molecularisation' in modern breeding. Koornneef and Stam (2001) describe how in plant breeding the paradigm has changed from selection of phenotypes toward indirect or direct selection of genes. Koebner and Summers (2003) however argue with respect to wheat breeding that the breeding paradigm will be touched but not overturned by genomics driven MAS, as wheat breeding will continue to be primarily driven by field selection. The representatives of the organic sector are not merely concerned about an overemphasis on increasing knowledge on the underlying 
molecular genetics, but also stress that the organic sector is urging for more knowledge on higher integration levels applying an agro-ecological approach at crop and farm system level. Nevertheless, to our opinion analytical tools such as markers can be of additional value in an approach that departs from a holistic view when the results of such an analysis are carefully converted to the level of farming and processing practices.

Beside the special concerns for MAS in organic farming, there are more general concerns on the use of markers for selection for quantitative traits, as there is still a large gap between phenotyping and genotyping of crops (e.g. $\mathrm{Xu}$ and Crouch 2008; Backes and Østergard 2008; Table 1, weakness). Although the efficiency of MAS largely depends on exact initial phenotyping, an even more effective way to bridge the gap and to deal with the interaction between genotype, environment and management (cultivation practices) is the opportunity given by integrating genetics, agronomy and crop physiology (Yin and Struik 2008; Struik and Yin 2009). Their approach, including QTL-based ecophysiological modeling, could also provide the tools to breed for complex trait, such as nutrient-use efficiency, in a more efficient way and making use of markers. Integrating more disciplines in breeding research is also what Moose and Mumm (2008) suggest in their commentary on the recent molecular advances to meet the challenge of identifying the best gene combinations for optimal crop improvement.

All the participating breeders acknowledged that there will always be a certain gap between genotype and phenotype as molecular markers will never give full information especially where there is more interaction of environment such as is the case under the varying low-input farming conditions. The breeders clearly stressed that in breeding programmes phenotypic selection will always be needed, and that research on developing easy phenotypic selection methods is still required. MAS will increase breeders' flexibility because it enables them to work with smaller populations and MAS can also lead to a more efficient use of field trial capacity (Heselmans 2009) (Table 1, Strengths). In conclusion, there is no need that molecular marker have to stand their ground as an exclusive selection tool, as they rather should be considered as a complement to phenotypic selection (Table 2, Weaknesses).
Better use of genetic diversity vs. loss of biodiversity

The emphasis of OA is on 'prevention management' based on ecological principles. This includes applying organic fertilisers to build up soil fertility, using a wide crop rotation, mechanical weed management, etc. Exploiting biodiversity is one of the central measures to create resilience within the farm ecosystem (Østergård et al. 2009b).

One of the strengths of MAS identified is the ability to improve the introgression of 'exotic' and wild alleles and thereby to increase the genetic diversity in the pool of available varieties. As biodiversity and thus also genetic diversity is one of the key tools of OA in building up resilience in the agro-ecosystems, technologies with this potential are of interest. As discussed above on the issue of backcrossing, marker-assisted introgression makes access to new genetic resources more feasible by screening genetic resources with molecular markers and by making selection of newly introduced quality or resistance alleles from wild relatives more efficient. The reason is that the targeted gene can more easily be followed in the successive generations of backcrossing and distinguished from undesired linkage drag (Hospital 2001).

However, although the participants from OA were positive about the above described strength, they also expressed the concern that too much focus on genetic markers may decrease diversity during the breeding process for economic reasons (Tables 1 and 2, Threats). This concern was also expressed in the policy paper of the Soil Association (Soil Association 2001). The breeders with molecular experience recognized this concern, but were more confident about the positive gains. The future practice will tell whether there is more chance to lose or to gain diversity by applying MAS in breeding.

'Clean' approach and evolving technology

Some of the issues put forward by OA concerned the assignment of instrumental values and were related to the potential positive or negative consequences of the use of molecular markers. Other arguments concerned the assignment of intrinsic values and were related to the methodology and protocols for the development of the molecular markers. This last 
aspect leads to one of the threats identified by the breeders that not all molecular marker technologies will be allowed in breeding programmes for OA (Table 1, Threats). This is related to one of the very important reservations of the organic sector against the use of molecular markers due to the fact that harmful chemicals and enzymes produced from genetically modified organisms are used in the process of marker development (Table 2, Weaknesses). At the same time a threat was identified that the development of protocols with non-genetically modified enzymes is slow and not of high priority (Table 2, Threats). One of the opportunities is that the general development within molecular techniques is moving towards replacing harmful chemicals by alternatives that cause less damage to the lab-workers and the environment (Table 1, Opportunities) (e.g. Yoza et al. 2002, Zipper et al. 2004).

For the enzymes required for the process, of which the heat-stable DNA polymerase for the PCR reaction is the most important, the common trend goes toward enzymes produced by recombinant micro-organisms; this is because of their higher efficiency and standardization of production. Nevertheless, most suppliers of Taq-polymerase offer the native (nonrecombinant) enzyme at only slightly higher prices. A minor disadvantage might be that advanced features engineered in the recombinant Taq-polymerase, like the activation by heat exposure in order to avoid premature enzyme activity, are not available for the native enzymes (Kellogg et al. 1994, Lebedev et al. 2008).

\section{Competition and costs}

An issue that is of concern of both breeders and the organic sector is related to the costs of marker application in MAS, both for investments and running costs (Table 1 and 2). Apart from other features, such as the resolving power, determined by the level of polymorphism detected, co-dominance and reproducibility (Xu and Crouch 2008) the costs are certainly an important factor in the breeder's choice of a specific type of marker. Costs, first of all depends on the possibilities for automation in a marker method. The use of agarose gels for visualization, for instance, require lower investment costs, but offer nearly no possibility of automation, while in the case of a detection on a sequencer, both the potential for automation and the investment costs are high. For the actual costs, it is important to separate development and application costs as in many cases the breeder will either rely on existing markers or include the marker development into publicly financed research projects (Backes and Østergard 2008).

The possible strategies for marker applications range from a complete 'in-house' solution to a complete outsourcing of all marker activities to a service provider. The most expensive solution would be to develop a marker 'from scratch' by establishing the linkage between marker and trait. Only large companies have the necessary scientific and budgetary capacity to meet this challenge. This fact results in concerns of small and medium-sized breeding companies that depend on the public availability of markers and fear not to be able to keep with those global players (Table 2, Weaknesses). Further, if a breeder applying MAS gets an advantage by being the first on the market with an improved trait for a certain crop, the competitors might like also to invest in molecular marker techniques. If these new techniques form a mere addendum to the established breeding process, this would certainly enhance the costs of plant breeding and, thereby, also increase the price of the seeds (Table 1, Threats). If, in contrast, the breeder is able to replace part of the phenotypic trials by MAS, it might be cost-neutral. However, new technologies that increase productivity have always an impact on the adapting company relative to its competitors. In addition, the development of better DNA extraction technologies and DNA analysis tools leading to decreasing cost per data point will make molecular marker strategies possible for budget restricted breeding programmes too (Weyen 2009).

An increasing number of service providers for MAS give also smaller breeding companies the freedom to choose to adopt or not to adopt MAS on a case by case basis without making larger investments in this technology themselves.

Breeding for organic farming still is a nichemarket of low interest for global players, which makes their competitiveness a less critical factor. The application of molecular markers in breeding companies challenges the ability of the breeder to reconsider an accustomed (and likely successful) breeding system and to acquire new skills to deal with this instrument (Table 1, weakness). The most 
important challenge might be to decide where and when it pays to replace or complement phenotypic selection for a specific trait by MAS.

\section{Education and communication}

Another concern that is shared by both the organic sector and breeders is that the emerging science of molecular genetics tend to generate more attention in breeding education, as most of the breeding research at the universities in which the students participate deals with molecular techniques (Tables 1 and 2, Threats). The private breeding sector requires a curriculum dealing with molecular techniques as well as with 'traditional', phenotype-based field selection in actual populations (Gepts and Hancock 2005). This may help to develop skills how molecular genetics can be incorporated into traditional breeding programmes (Ransom et al. 2006).

The rejection of genetic engineering by the organic sector and promoting traditional, phenotype based selection does not imply that there is no innovation in breeding for organic agriculture. On the contrary, organic agriculture challenges the breeding sector to broaden the scope of approaches by including (additional) morphological and physiological traits (Burger et al. 2008, Löschenberger et al. 2008, Osman et al. 2008, Pswarayi et al. 2008, Voorrips et al. 2008). Breeders as well as the organic sector stressed that acceptance of the use of molecular technology in OA requires good communication (Tables 1 and 2, Weaknesses). Although it may be difficult for farmers and consumers to understand and accept MAS in OA, as it is too much associated with genetic engineering (Table 2, Threats), there are interesting examples of needs for varietal improvement with a role for MAS. Emphasizing these examples may help in getting acceptance for the use of molecular technology in OA.

The workshop revealed that there is a lack of knowledge in organic sector on the pros and cons of molecular markers and marker assisted selection and that there is not much active interaction and communication between the organic sector and molecular scientists.

Many scientists tend to believe that a broad public understanding of each and any detail in science and technology is an indispensible prerequisite for public acceptance of new technologies and the applications thereof. This belief has resulted in communication strategies that flood the public with large amounts of information about new technologies and the benefits of potential applications (Office of Science and Technology 2000). We seriously doubt whether it is useful to explain MAS to the general public as our own experience is that organic consumers (laypersons) even question the need for (traditional) breeding as such assuming that old varieties are the best to apply and have difficulties to understand technical aspects. In our opinion it would make more sense to discuss the use of molecular markers with (organic) farmers as the first line users. However, it would be worthwhile to put more emphasis on educating the public that plant breeding is a natural component of agriculture in general and also for organic agriculture.

\section{Conclusions and perspectives}

This workshop contributed to bridging of the gap between the organic sector and molecular scientists. The discussions were very fruitful, open and respectful with regards to the different positions of the participants and the SWOT instrument helped to summarize the issues. It was noted that not only had the participants from the organic sector learned from the molecular scientists and ended up to be more open for the strengths and opportunities, but also vice versa the molecular scientists better understood the concerns having learned more of the underlying arguments based on the values of organic agriculture. Compared to results in 2005 there is less skepticism, and there is more space for nuances: the organic sector is not per se opposed to high tech methods but can embrace such technology in carefully argued and designed cases respecting conditions for the application of MAS in plant breeding for organic agriculture, see also Soil Association (2001).

A major conclusion of the workshop is that more interaction between organic and molecular oriented breeders can benefit both research communities. They represent two different but not incompatible ways of approaching breeding problems. The interaction during the workshop resulted in more awareness of the possibilities to combine approaches case by case.

In conclusion, the extent to which MAS can be used efficiently in breeding for organic farming to complement and to replace part of the phenotypic 
selection will be highly dependent on the specific trait and the availability of markers that reflect the genetic basis of the special needs for organic farming.

With respect to the organic sector there is a need to show and discuss with molecular scientists examples of 'good practices' of breeding and research projects with MAS approaches as well as be updated on how new protocols may be adapted. Then case by case make the strategic decision based on further SWOT analyses. Finally, in research and education programmes we have to promote a balance between molecular and non-molecular methods and skills by paying more attention to the opportunities of improved phenotypic selection.

Acknowledgments The authors thank the participants in the Bioexploit/Eucarpia workshop for their contribution to the SWOT analysis, and would also like to thank one of the anonymous reviewers for the valuable comments to improve the manuscript. The authors gratefully acknowledge funding from the European Community financial participation under the Sixth Framework Programme for Research, Technological Development and Demonstration Activities, for the EU Integrated Projects Bioexploit (Exploitation of natural plant biodiversity for the pesticide-free production of food) FOODCT-2005-513959 and EU SOL (High Quality Solanaceous Crops for Consumers, Processors and Producers by exploring of natural biodiversity) FOOD-CT-2006-016214, and the Eucarpia Section Organic and Low-input Agriculture.

Open Access This article is distributed under the terms of the Creative Commons Attribution Noncommercial License which permits any noncommercial use, distribution, and reproduction in any medium, provided the original author(s) and source are credited.

\section{References}

Andersen JR, Lübberstedt T (2003) Functional markers in plants. Trends Plant Sci 8:554-560

Backes G, Østergard H (2008) Molecular markers to exploit genotype-environment interactions of relevance in organic growing systems. Euphytica 163:523-531

Burger H, Schloen M, Schmidt W, Geiger HH (2008) Quantitative genetic studies on breeding maize for adaptation to organic farming. Euphytica 163:501-510

Collard BCY, Jahufer MZZ, Brower JB, Pang ECK (2005) An introduction to markers, quantitative trait loci (QTL) mapping and marker-assisted selection for crop improvement: the basic concepts. Euphytica 142:169-196

Council of the European Union (2007) Council regulation (EC) No 834/2007 of 28 June 2007 on organic production and labelling of organic products and repealing regulation (EEC) No 2092/91. http://eur-lex.europa.eu/LexUriServ/ site/en/oj/2007/1_189/1_18920070720en00010023.pdf. Accessed Oct 2009

Dawson JC, Goldringer I (2009) Direct or indirect selection in breeding for organic agriculture. In: Østergård $\mathrm{H}$, Lammerts van Bueren ET, Bouwman-Smits L (eds) Proceedings of the BioExploit/Eucarpia workshop on the role of marker assisted selection in breeding varieties for organic agriculture, BioExploit, Wageningen, The Netherlands, pp 15-18, 25-27 February, 2009. http://www. eucarpia.org/. Accessed 14 Oct 2009

Dwivedi SL, Crouch JH, Mackill DJ, Xu Y, Blair MW, Ragot M, Upadhyaya HD, Ortiz R (2007) The molecularization of public sector crop breeding: progress, problems and prospects. Adv Agron 95:163-318

Enjalbert J, Goldringer I, Paillard S, Brabant P (1999) Molecular markers to study genetic drift and selection in wheat populations. J Exp Bot 50:283-290

Finckh MR (2009) Required characteristics for organic wheat varieties with respect to disease resistance. In: Østergård $\mathrm{H}$, Lammerts van Bueren ET, Bouwman-Smits L (eds) Proceedings of the BioExploit/Eucarpia workshop on the role of marker assisted selection in breeding varieties for organic agriculture, BioExploit, Wageningen, The Netherlands, pp 25-27, 25-27 February 2009. http://www. eucarpia.org/. Accessed 14 Oct 2009

Gepts P, Hancock J (2005) The future of plant breeding. Crop Sci 46:1630-1634

Grausgruber H (2009) Organic plant breeding - a general overview. In: Østergård H, Lammerts van Bueren ET, Bouwman-Smits L (eds) Proceedings of the BioExploit/ Eucarpia workshop on the role of marker assisted selection in breeding varieties for organic agriculture, BioExploit, Wageningen, The Netherlands, pp 11-14, 25-27 February 2009. http://www.eucarpia.org/. Accessed Oct 2009

Gupta PK, Rustgi S, Kulwal PL (2005) Linkage disequilibrium and association studies in higher plants: present status and future prospects. Plant Mol Biol 57:461-485

Haas BJ, Kamoun S, Sody MC et al (2009) Genome sequence and analysis of the Irish potato famine pathogen Phytophthora infestans. Nature 461:393-398

Heselmans AFM (2009) Tracing resistance genes in potato by MAS in a professional breeding program. In: Østergård $\mathrm{H}$, Lammerts van Bueren ET, Bouwman-Smits L (eds) Proceedings of the BioExploit/Eucarpia workshop on the role of marker assisted selection in breeding varieties for organic agriculture, BioExploit, Wageningen, The Netherlands, 25-27 February 2009. http://www.eucarpia.org. Accessed 14 Oct 2009

Hospital F (2001) The reduction of linkage drag around introgressions in marker-assisted backcross programs. In: Gallais A, Dillmann C, Goldringer I (eds), Quantitative genetics and breeding methods: the way ahead, proceedings of the 11th meeting Eucarpia section biometrics in plant breeding, Editions INRA, Paris, Les Colloques $\mathrm{n}^{\circ}$ 96, 30 August-1 September 2000, pp 199-204

IFOAM (2005) Principles of organic agriculture. http://www. ifoam.org/about_ifoam/principles/. Accessed 15 Oct 2009

Kellogg DE, Rybalkin I, Chen S, Mukhamedova N, Vlasik T, Siebert PD, Chenchik A (1994) TaqStart Antibody: "hot start" PCR facilitated by a neutralizing monoclonal 
antibody directed against Taq DNA polymerase. BioTechniques 16:1134-1137

Kephart SR (1990) Starch gel electrophoresis of plant isozymes: a comparative analysis of techniques. Am J Bot 77:693-712

Keygene (2009) KeyGene and amplicon express announce whole genome profiling, a method that enables fast and efficient whole genome sequencing of plant and animal genomes. Keygene Press Release, January 12 2009. http:// www.keygene.com/keygene/pdf/PR\%20Amplicon_WGP. pdf. Accessed 15 Oct 2009

Koebner RMD, Summers RW (2003) 21st century wheat breeding: plot selection or plate detection? Trends Biotechnol 21:59-63

Koornneef M, Stam P (2001) Changing paradigms in plant breeding. Plant Physiol 125:156-159

Lammerts van Bueren ET, Struik PC, Jacobsen E (2002) Ecological aspects in organic farming and its consequences for an organic crop ideotype. Neth J Agr Sci 50:1-26

Lammerts van Bueren ET, Goldringer I, Østergård H (2005) Proceedings of the COST SUSVAR/ECO-PB workshop on organic plant breeding strategies and the use of molecular markers, Louis Bolk Institute, Driebergen, The Netherlands, 17-19 January 2005

Lammerts van Bueren ET, Verhoog H, Tiemens-Hulscher M, Struik PC, Haring MA (2007) Organic agriculture requires process rather than product evaluation of novel breeding techniques. NJAS Wageningen J Life Sci 54:401-412

Lammerts van Bueren ET, Tiemens-Hulscher M, Struik PC (2008) Cisgenesis does not solve the late blight problem of organic potato production: alternative breeding strategies. Potato Res 51:89-99

Lançon J, Pichaut J-P, Djaboutou M, Lewicki-Dhainaut S, Viot C, Lacape J-M (2008) Use of molecular markers in participatory plant breeding: assessing the genetic variability in cotton populations bred by farmers. Ann Appl Biol 152:113-119

Lebedev AV, Paul N, Yee J, Timoshchuk VA, Shum J, Miyagi K, Kellum J, Hogrefe RI, Zon G (2008) Hot start PCR with heat-activatable primers: a novel approach for improved PCR performance. Nucleic Acids Res 36:e131. doi:10.1093/nar/gkn575

Lodish H, Berk A, Matsudaira P, Kaiser CA, Krieger M, Scott MP, Zipursky SL, Darnell J (2004) Molecular biology of the cell, WH Freeman, New York

Löschenberger F, Fleck A, Grausgruber H, Hetzendorfer H, Hof G, Lafferty J, Marn M, Neumayer A, Pfaffinger G, Birschitzky J (2008) Breeding for organic agriculture-the example of winter wheat in Austria. Euphytica 163:469-480

Luttikholt LWM (2009) Principles of organic agriculture. In: Østergård $\mathrm{H}$, Lammerts van Bueren ET, Bouwman-Smits L (eds) Proceedings of the BioExploit/Eucarpia workshop on the role of marker assisted selection in breeding varieties for organic agriculture, BioExploit, Wageningen, The Netherlands, pp 46-50, 25-27 February 2009. http://www.eucarpia.org/. Accessed 14 Oct 2009

Mason HE, Spaner D (2006) Competitive ability of wheat in conventional and organic management systems: a review of the literature. Can J Plant Sci 86:333-343
Mollenhorst H, de Boer IJM (2004) Identifying sustainability issues using participatory SWOT analysis-a case study of egg production in the Netherlands. Outlook Agric 33:267-276

Moose SP, Mumm RH (2008) Molecular plant breeding as the foundation for 21 st century crop improvement. Plant Physiol 147:969-977

Office of Science and Technology (2000) Science and the public: a review of science communication and public attitudes to science in Britain. Department of Trade and Industry and the Trustee of the Wellcome Trust. http:// www.wellcome.ac.uk/stellent/groups/corporatesite/@msh_ peda/documents/web_document/wtd003419.pdf. Accessed 15 Oct 2009

Osman AM, Struik PC, Almekinders CJM, Lammerts van Bueren ET (2008) Can onion varieties suitable for organic farming be obtained through conventional breeding programmes? Euphytica 163:511-522

Østergård H, Backes G, Kovács G (2007) Proceedings of the COST SUSVAR workshop on varietal characteristics of cereals in different growing systems with special emphasis on below ground traits, Ris $\varnothing$ National Laboratory, Roskilde, Denmark, 29-31 May 2007. http://www.cost860. dk/publications/proceedings.asp. Accessed 14 Oct 2009

Østergård H, Lammerts van Bueren ET, Bouwman-Smits L (2009) Proceedings of the BioExploit/Eucarpia workshop on The role of Marker Assisted Selection in breeding varieties for organic agriculture, BioExploit, Wageningen, The Netherlands, 25-27 February 2009. http://www. bioexploit.net/ or http://www.eucarpia.org/. Accessed Oct 2009

Østergård H, Finckh MR, Fontaine L, Goldringer I, Hoad SP, Kristensen K, Lammerts van Bueren ET, Mascher F, Munk L, Wolfe MS (2009b) Time for a shift in crop production: embracing complexity through diversity at all levels. J Sci Food Agric 89:1439-1445

Pswarayi A, van Eeuwijk FA, Ceccarelli S, Grando S, Comadran J, Russell JR, Pecchion N, Tondelli A, Akar T, AlYassin A, Benbelkacem A, Ouabbou H, Thomas WT, Romagosa I (2008) Changes in allele frequencies in landraces, old and modern barley cultivars of marker loci close to QTL for grain yield under high and low input conditions. Euphytica 163:435-447

Ransom C, Patricka C, Ando K, Olmstead J (2006) Report of breakout group 1. What kind of training do plant breeders need, and how can we most effectively provide that training? HortScience 41:53-54

Soil Association (2001) Campaigning for organic food and farming and sustainable forestry-marker assisted plant breeding, The Soil Association, Bristol, United Kingdom. http://www.biotech-info.net/marker_assisted_breeding2. html. Accessed 15 Oct 2009

Struik PC, Yin X (2009) QTL x E x M: combining crop physiology and genetics. In: Østergård $\mathrm{H}$, Lammerts van Bueren ET, Bouwman-Smits L (eds) Proceedings of the BioExploit/Eucarpia workshop on the role of marker assisted selection in breeding varieties for organic agriculture, BioExploit, Wageningen, The Netherlands, pp 19-22, 25-27 February 2009. http://www.eucarpia.org/. Accessed 14 Oct 2009 
Tan MYA (2008) Genetic mapping and pyramiding of resistance genes in potato. $\mathrm{PhD}$ thesis Wageningen University, The Netherlands

Triboï E, Martre P, Triboï-Blondel A-M (2003) Environmentally-induced changes in protein composition in developing grains of wheat are related to changes in total protein content. J Exp Bot 54:1731-1742

Tuvesson S, Dayteg C, Hagberg P, Manninen O, Tanhuanpää P, Tenhola-Roininen T, Kiviharju E, Weyen J, Förster J, Schondelmaier J, Lafferty J, Marn M, Fleck A (2007) Molecular markers and doubled haploids in European plant breeding programmes. Euphytica 158:305-312

Tuvesson S, Svensson E, Happstadius I, Henriksson T, Kazman E (2009) Application of markers when breeding for baking quality. In: Østergård $\mathrm{H}$, Lammerts van Bueren ET, Bouwman-Smits L (eds) Proceedings of the BioExploit/ Eucarpia workshop on the role of marker assisted selection in breeding varieties for organic agriculture, BioExploit, Wageningen, The Netherlands, pp 38-39, 25-27 February 2009. http://www.eucarpia.org/. Accessed Oct 2009

USDA (2002) National organic program, United States Department of Agriculture, Agricultural Marketing Service, 7 CFR Part 205. http://www.ams.usda.gov/AMSv1.0/ ams.fetchTemplateData.do?template $=$ TemplateF\&navID $=$ RegulationsNOPNationalOrganicProgramHome\&rightNav1 $=$ RegulationsNOPNationalOrganicProgramHome\&topNav= \&leftNav=NationalOrganicProgram \&page=NOPRegulations $\&$ resultType $=\&$ acct $=$ noprulemaking. Accessed Oct 2009

Verhoog H (2007) Organic agriculture versus genetic engineering. NJAS Wageningen J Life Sci 54:387-400

Voorrips RE, Steenhuis-Broers G, Tiemens-Hulscher M, Lammerts van Bueren ET (2008) Plant traits associated with resistance to Thrips tabaci in cabbage (Brassica oleracea var capitata). Euphytica 163:409-416

Vos N (2009). Organic potato breeding creates added value. In: Østergård H, Lammerts van Bueren ET, Bouwman-Smits L (eds) Proceedings of the BioExploit/Eucarpia workshop on the role of marker assisted selection in breeding varieties for organic agriculture, BioExploit, Wageningen, The Netherlands, p 32, 25-27 February 2009. http:// www.eucarpia.org/. Accessed 14 Oct 2009
Weyen J (2009) How MAS is included in wheat breeding programmes for disease resistance. In: Østergård $\mathrm{H}$, Lammerts van Bueren ET, Bouwman-Smits L (eds) Proceedings of the BioExploit/Eucarpia workshop on the role of marker assisted selection in breeding varieties for organic agriculture, BioExploit, Wageningen, The Netherlands, pp 28-29, 25-27 February 2009. http://www. eucarpia.org/. Accessed Oct 2009

Wieser H, Seilmeier W (1998) The influence of nitrogen fertilisation on quantities and proportions of different protein types in wheat flour. J Sci Food Agric 76:49-55

Wolfe MS (2009) Is heterogeneity an advantage or a disadvantage in breeding for baking quality in wheat. In: Østergård H, Lammerts van Bueren ET, Bouwman-Smits L (eds) Proceedings of the BioExploit/Eucarpia workshop on the role of marker assisted selection in breeding varieties for organic agriculture, BioExploit, Wageningen, The Netherlands, pp 34-37, 25-27 February 2009. http://www.eucarpia.org/. Accessed 14 Oct 2009

Wolfe MS, Baresel JP, Desclaux D, Goldringer I, Hoad S, Kovacs G, Löschenberger F, Miedaner T, Østergård H, Lammerts van Bueren ET (2008) Developments in breeding cereals for organic agriculture. Euphytica 163:323-346

Xu Y, Crouch JH (2008) Marker-assisted selection in plant breeding: from publications to practice. Crop Sci 48:391407

Yin X, Struik PC (2008) Applying modelling experiences from the past to shape crop systems biology: the need to converge crop physiology and functional genomics. New Phytol 179:629-642

Yin X, Stam P, Kropff MJ, Schapendonk AHCM (2003) Crop modeling, QTL mapping, and their complementary role in plant breeding. Agron J 95:90-98

Yoza B, Matsumoto M, Matsunaga T (2002) DNA extraction using modified bacterial magnetic particles in the presence of amino silane compound. J Biotechnol 94:217-224

Zipper H, Brunner H, Bernhagen J, Vitzthum F (2004) Investigations on DNA intercalation and surface binding by SYBR Green I, its structure determination and methodological implications. Nucl Acids Res 32:e103. doi:10. 1093/nar/gnh101 